\title{
Desain dan Implementasi Peralatan Deteksi Arcing Tegangan Rendah Berbasis LabView
}

\author{
Azmi Wicaksono, Dimas Anton Asfani dan I Made Yulistya Negara \\ Jurusan Teknik Elektro, Fakultas Teknologi Industri, Institut Teknologi Sepuluh Nopember (ITS) \\ Jl. Arief Rahman Hakim, Surabaya 60111 \\ e-mail: anton@ee.its.ac.id; yulistya@ee.its.ac.id
}

\begin{abstract}
Abstrak - Busur api listrik tegangan rendah timbul saat terjadi hubung singkat dan memicu kebakaran. Fenomena hubung singkat terjadi saat peralatan pengaman tidak dapat mendeteksi gangguan yang terjadi, meskipun nominal arus saat terjadi hubung singkat sangat tinggi namun durasi hubung singkat sangat cepat sehingga peralatan pengaman konvensional seperti fuse dan circuit breaker (CB) tidak dapat mendeteksi gangguan tersebut, hal inilah yang menimbulkan kebakaran karena hubung singkat. Pada Penelitian ini akan dilakukan pendeteksian arcing pada tegangan rendah dengan mengamati karakteristik arus busur api yang meningkat secara signifikan pada durasi waktu tertentu. Sinyal arus yang masuk akan ditransformasikan menggunakan wavelet. Eksperimen dilakukan dengan membandingkan 3 kondisi yaitu kondisi normal, penambahan beban (switching) serta arcing. Terdapat 2 batas (threshold) yang digunakan sebagai parameter pendeteksian. Threshold pertama adalah nilai arus high frequency maksimum 2A dan yang kedua adalah jumlah titik gangguan sebanyak 7. Berdasarkan hasil pendeteksian, indikator normal akan "ON" selama threshold pertama dan kedua tidak terlampaui, indikator switching "ON" saat threshold pertama terlampaui namun threshold kedua tidak, sedangkan indikator arcing "ON" saat kedua threshold terlampaui.
\end{abstract}

Kata Kunci - Busur Api Listrik Tegangan Rendah, Transformasi Wavelet, Threshold arus HF, Threshold titik gangguan

\section{PENDAHULUAN}

$\mathrm{L}$ ISTRIK dalam kehidupan sehari-hari menjadi kebutuhan yang sangat penting dan utama bagi setiap masyarakat. Pengguna energi listrik di Indonesia meningkat tiap tahunnya, hal ini dapat dilihat dari meningkatnya rasio elektrifikasi yang ada di Indonesia, khususnya pelanggan rumah tangga di pemukiman padat penduduk. Hal ini menyebabkan setiap wilayah di Indonesia memiliki rasio elektrifikasi yang terus meningkat setiap tahunnya. Menurut data Perusahaan Listrik Negara (PLN) tentang rasio elektrifikasi di Indonesia mencapai $63,5 \%$ pada tahun 2011, kemudian setiap tahunnya bertambah $4-5 \%$ sehingga pada tahun 2013 rasio elektrifikasi menjadi 84,0\%. Permintaan listrik yang semakin besar berbanding lurus dengan penyedia jasa listrik serta instalasi listrik pada pemukiman, hal ini ditunjukkan melalui data statistik Perusahaan Listrik Negara (PLN), bahwa pada tahun 2011 penjualan serta pemintaan pemasangan tenaga listrik di sektor pelanggan rumah tangga meningkat sebesar 9\%. Namun seiring dengan bertambahnya permintaan listrik pada pemukiman tidak diimbangi dengan instalasi yang baik, sehingga ada banyak masalah yang timbul dikemudian hari seperti korsleting listrik dan kebakaran.

Salah satu masalah yang ditimbulkan akibat instalasi listrik yang kurang baik adalah korsleting listrik dan memicu kebakaran. Menurut Badan Nasional Penanggulangan
Bencana dari akhir tahun 2011 hingga pertengahan tahun 2015 ada 979 kasus kebakaran yang ada di Indonesia dengan 431 yang disebabkan oleh korsleting listrik.

Kasus - kasus kebakaran terjadi karena ketidakmampuan peralatan proteksi atau pengaman pada level tegangan rendah untuk mendeteksi dan mengatasi gangguan hubung singkat, sehingga timbul arcflash atau busur api yang akan menyebabkan kebakaran. Gangguan hubung singkat pada tegangan menengah atau tegangan tinggi biasanya dapat dideteksi oleh rele arus lebih karena arusnya yang sangat besar dibanding overload, namun hal ini hanya berlaku jika gangguan bersifat terus menerus (continue). Namun untuk gangguan hubung singkat pada tegangan rendah tidak dapat terdeteksi karena karakteristiknya yang berbeda dibanding short circuit di level tegangan lain. Hal inilah yang menyebabkan busur api tidak dapat diatasi dan menyebabkan kebakaran.

\section{URAIAN PENELITIAN}

\section{A. Arcing Fault di Tegangan Rendah}

Arcing fault yaitu percikan api atau busur api pada sistem tenaga lisrik yang terjadi ketika dua permukaan konduktor mendekat secara bersamaan dan bersentuhan. Fenomena ini dinamakan hubung-singkat, dan terjadi lompatan arus melewati sela antara kedua kabel konduktor karena nilai tegangan yang cukup. Percikan inilah yang kemudian mengionisasi udara di sekitar, sehingga udara di sekitar menjadi konduktif dan membentuk arc atau busur api [1]. Menurut NFPA [2], Arcflash merupakan fenomena pelepasan energi yang berbentuk panas dan cahaya dari proses ionisasi (perbanyakan elektron) yang terjadi di udara dari sebuah bahan atau material.

Busur api disebabkan oleh 2 konduktor yang memiliki beda potensial dan saling bersentuhan yang kemudian menyebabkan kegagalan isolasi. Apabila isolasi yang melindungi suatu bagian konduktor bertegangan rusak sehingga bagian tersebut menyentuh bagian konduktor lain dengan potensial yang berbeda dapat menyebabkan terjadinya arc flash [3]. Fenomena arcflash memegang peran penting saat terjadi kebakaran. Peralatan-peralatan pengaman konvensional seperti MCB (Miniatur Circuit Breaker) dan fuse tidak dapat mendeteksi arus yang sangat tinggi dan melakukan trip sesuai ekspektasi. Hal ini disebabkan karena durasi terjadinya hubung singkat sangat cepat sehingga tidak dapat dideteksi oleh peralatan pengaman konvensional seperti MCB tau fuse [4-6]. Kegagalan isolasi juga terjadi karena gangguan, yaitu berupa gangguan internal maupun gangguan eksternal. Gangguan internal yaitu gangguan yang berasal dari dalam bahan isolasi itu sendiri. Penuaan (aging) yang berkaitan dengan umur kabel serta bahan isolasi yang mudah rapuh dan mudah rusak menjadi salah satu gangguan 
internal. Sedangkan, gangguan eksternal seperti gigitan hewan pengerat (tikus). Kedua faktor gangguan ini menyebabkan kegagalan isolasi sehingga arus (fasa) dapat keluar dari isolatornya dan terjadi hubung singkat dengan kabel didalamnya atau dengan konduktor lain (netral). Pada level tegangan rendah, secara umum terdapat 2 jenis kabel yang digunakan dalam instalasi yaitu kabel konduktor tunggal dan kabel konduktor serabut. Kabel konduktor serabut tegangan rendah yang digunakan memilki ukuran diameter yang bermacam-macam yaitu $0,75 \mathrm{~mm}^{2}, 1,5 \mathrm{~mm}^{2}$, $2,5 \mathrm{~mm}^{2}$ dan lain sebagainya. Setiap ukuran diameter kabel memiliki ketahanan arus yang berbeda beda, ini disebabkan karena nilai impedansi saluran dipengaruhi oleh jenis inti dan diameter inti kabel yang digunakan [8].

\section{B. Karakteristik Busur Api Listrik pada Beban Resistif}

Beberapa karakteristik umum arus busur api listrik pada beban resistif yang telah diidentifikasi antara lain [10]:

1. Di setiap setengah cycle, arus arcing akan bernilai mendekati nol atau padam sebelum terjadi gangguan dan naik kembali setelah melewati titik nol.

2. Laju kenaikan dan puncak dari arus arcing biasanya selalu lebih besar dibanding arus beban normal.

3. Banyak metode pendeteksian arcing yang digunkan berbasis monitoring arus, dengan mengidentifikasi karakteristik yang berbeda dari arc fault.

4. Salah satu metodenya yaitu menggunakan komponen High-frequency (dari 10 kilohertz hingga $1 \mathrm{GHz}$ ), dengan menganalisis karakteristik yang signifikan seperti arus maksimum (peaks) dan laju kenaikan dari arus tersebut.

\section{EKSPERIMEN, PENGAMBILAN DAN PENGOLAHAN DATA}

\section{A. Perancangan Alat Eksperimen}

Perancangan alat eksperimen ini bertujuan untuk mensimulasikan serta memodelkan fenomena 3 kondisi yang umum terjadi pada penggunaan listrik tegangan rendah, yaitu kondisi beban normal, kondisi penambahan beban switching serta kondisi gangguan arcing. Skema alat eksperimen ditunjukkan Gambar 3.

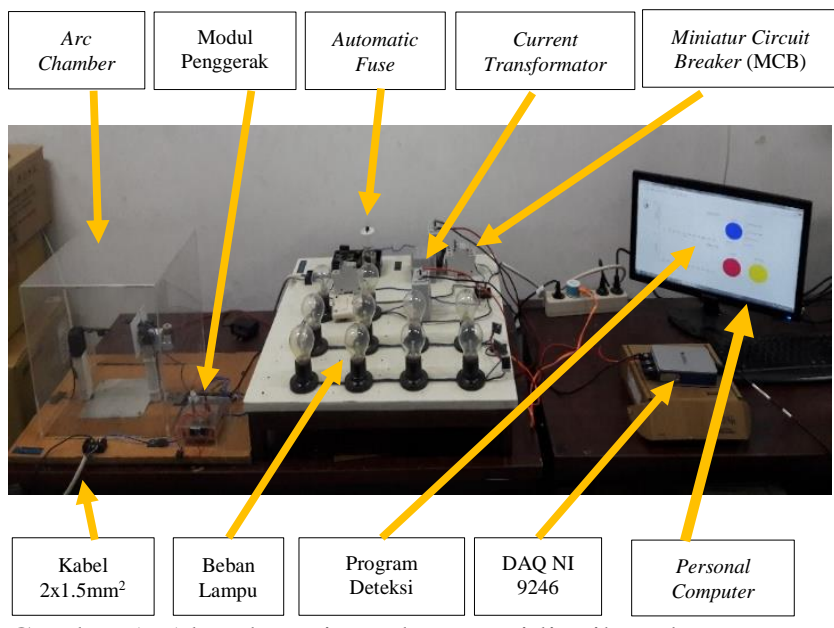

Gambar 1. Alat eksperimen busur api listrik pada tegangan rendah.

Alat eksperimen untuk mensimulasikan dan memodelkan 3 kondisi tersebut terdiri dari hardware dan software. Hardware yang digunakan adalah lampu 100 Watt sebanyak
10 buah, Current Transformator (CT) sebanyak 2 buah dengan rasio 200/5, sekering otomatis (fuse) 6A, fusebox, kabel konduktor serabut 1 fasa dengan ukuran penampang 1,5 $\mathrm{mm}^{2}$ (kabel NYMHY $2 \times 1,5 \mathrm{~mm}^{2}$ ), miniatur circuit breaker (MCB), chamber arkilik, saklar switching, NI DAQ 9246 sebagai perangkat perekam arus. Sedangkan software yang digunakan untuk mendukung eksperimen ini adalah LabView

\section{B. Pengambilan Data}

Alat yang digunakan dalam pengambilan data adalah NI 9246, yang merupakan komponen perekam arus. Pengambilan data eksperimen ini meliputi arus beban, arus arcing saat terjadi hubung-singkat pada kabel. Data arus beban yang dapat dijadikan kondisi normal atau switching serta arus arcing menggunakan frekuensi sampling 5k Samples/s. Pengambilan data pada beban lampu (resistif) kondisi normal dimulai dari 1 lampu hingga 10 lampu, dengan masing-masing jumlah lampu dilakukan 10x percobaan. Untuk pengambilan data arus switching, dilakukan penambahan beban lampu resistif dengan jumlah 1 lampu hingga 10 lampu, dengan masing-masing switching dilakukan 10x percobaan. Percobaan eskperimen busur api listrik dengan variasi jumlah serabut sebanyak 1 serabut, 3 serabut, 6 serabut, 12 serabut, dan 24 serabut dengan masingmasing percobaan sebanyak $5 x$.

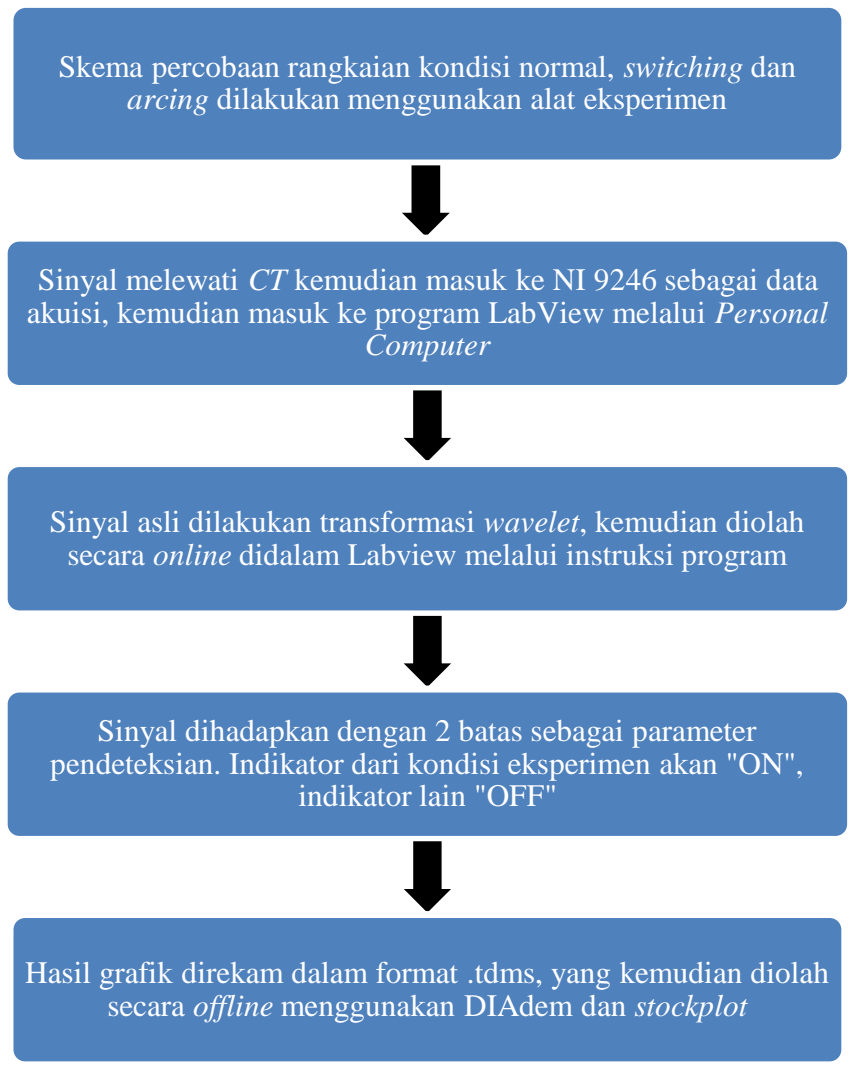

Gambar 2. Alur Pengambilan dan Pengolahan Data

\section{Pengolahan Data}

LabView menjadi software untuk mengolah sinyal sehingga tampilan user interface LabView dapat mendeteksi \& membedakan secara online 3 kondisi yang terjadi yaitu kondisi normal, switching serta arcing. Arus yang masuk melalui CT akan ditransformasikan kembali menjadi sinyal 
asli pada program LabView, sehingga arus yang muncul pada grafik memiliki amplitudo yang sama seperti arus asli dari eksperimen yang dilakukan. Selanjutnya, sinyal asli akan dilakukan proses konvolusi transformasi wavelet dengan program diagram blok yang sudah dibuat pada virtual instrument panel. Grafik HF ditampilkan pada user interface program pendeteksian. Diagram blok LabView juga mengolah sinyal yang masuk menjadi sebuah array yang dapat dianalisis setiap satuan datanya. Setiap data yang masuk dari sebuah sinyal akan dibandingkan dengan batasbatas (threshold) tertentu yang dapat diubah-ubah. Terdapat 2 batas yang dilakukan pada pengolahan data, yaitu batas nilai arus HF serta batas minimum jumlah titik HF yang melewati threshold arus.

\section{HASIL DAN ANALISIS DATA}

A. Skema Percobaan Karakteristik Arus Kondisi Normal, Switching dan Hubung Singkat Tegangan Rendah

Analisis dilakukan dengan pemotongan data karena data yang direkam cukup banyak sehingga diperlukan pemotongan data agar mudah dalam proses analisis. Dengan frekuensi sampling $5 \mathrm{k} / \mathrm{s}$, maka data tersebut akan dianalisis setiap 50 data, hal ini diperoleh :

$$
1 / 2 \text { cycle }=1 / 2 \frac{\text { frekuensi sampling }}{50}=\frac{1}{2} x \frac{5000}{50}=50
$$

Analisis karakteristik kondisi normal, switching dan arcing pada tegangan rendah meliputi arus beban, arus hubung-singkat, durasi terjadinya switching, arus maksimum, durasi terjadinya arcing, jumlah titik yang melebihi threshold arus, serta jumlah arcing yang muncul selama eksperimen. Analisis dilakukan dengan mempertimbangkan pengaruh variasi jumlah lampu yang terpasang (kondisi normal), variasi jumlah lampu yang ditambahkan (kondisi switching) dan jumlah serabut yang digunakan (kondisi arcing). Hasil dari data tersebut menjadi konten utama dalam program pendeteksian arcing pada tegangan rendah.

\section{B. Analisis Data Karakteristik Kondisi Normal dan Switching pada Tegangan Rendah}

Eksperimen kondisi normal menggunakan beban 1 lampu sampai dengan 10 lampu. Penggunaan 10 lampu dengan masing masing lampu 100 watt sehingga total daya 1000 watt. Sedangkan untuk kondisi switching digunakan penambahan jumlah lampu dari mulai 1 lampu hingga 10 lampu sehingga total beban 1100 watt dipilih karena sesuai dengan keadaan lapangan yang pada umumnya berlangganan 900 VA maupun 1200 VA dengan arus maksimum sekitar 5 A dan tegangan yang digunakan adalah jala-jalan $220 \mathrm{~V}$.

1. Perbandingan Arus Maksimum dan Jumlah Titik Gangguan Kondisi Normal dan Switching

Arus maksimum adalah arus dengan nilai amplitudo arus HF (high frequency) yang paling tinggi saat eksperimen normal dan switching dilakukan. Eksperimen kondisi beban normal dan switching juga memperhatikan berapa banyak jumlah titik arus HF yang bernilai lebih besar dibandingkan threshold arus. Penetuan jumlah titik yang berada diatas threshold arus akan ditampilkan pada user interface program deteksi arcing tersebut secara online atau dapat kita amati dengan bantuan toolbar report pada software Diadem.

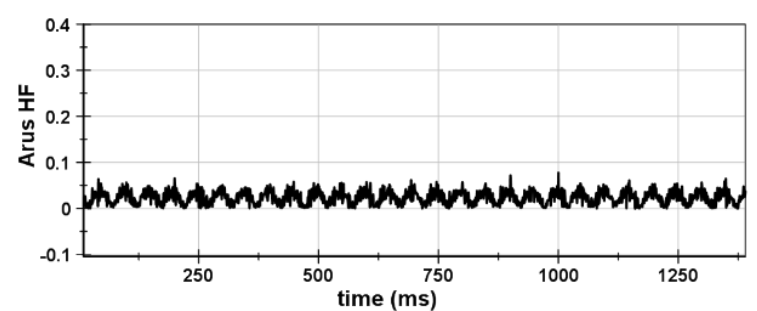

Gambar 3. Grafik kondisi normal 1 Lampu

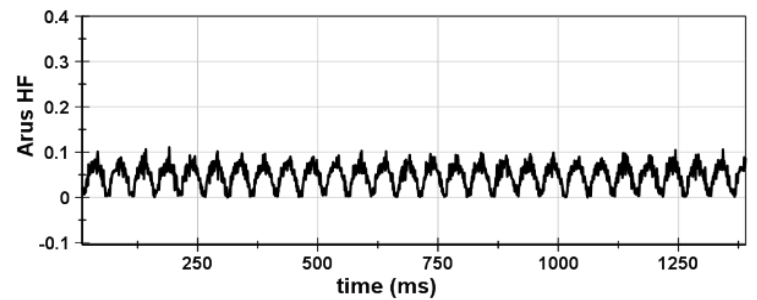

Gambar 4. Grafik kondisi normal 2 Lampu

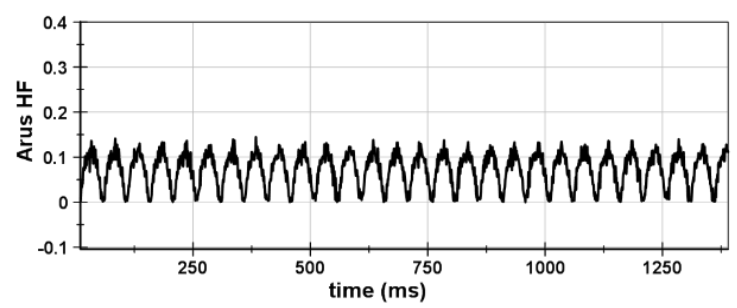

Gambar 5. Grafik kondisi normal 3 Lampu

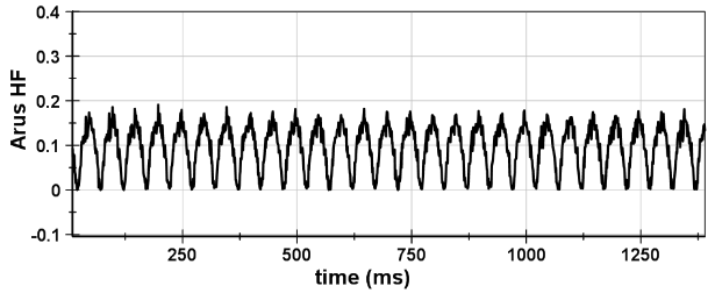

Gambar 6. Grafik kondisi normal 4 Lampu

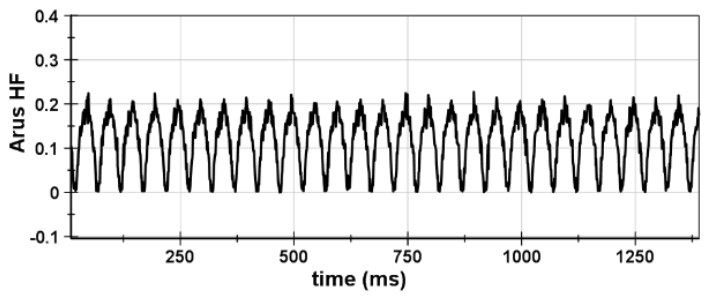

Gambar 7. Grafik kondisi normal 5 Lampu

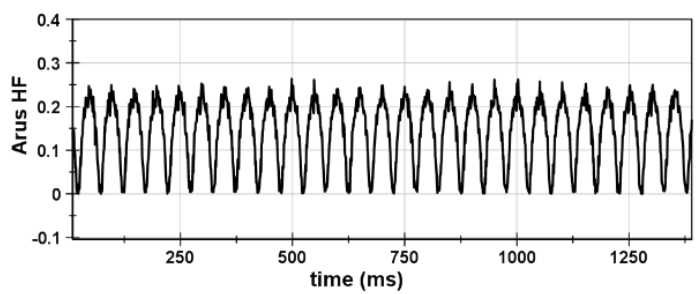

Gambar 8. Grafik kondisi normal 6 Lampu

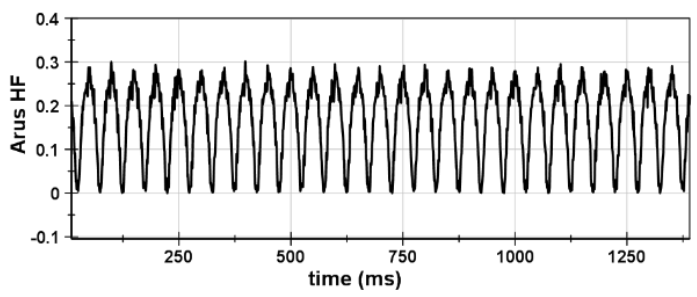

Gambar 9. Grafik kondisi normal 7 Lampu 


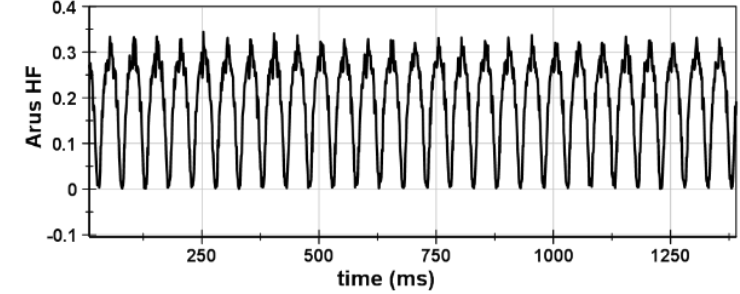

Gambar 10. Grafik kondisi normal 8 Lampu

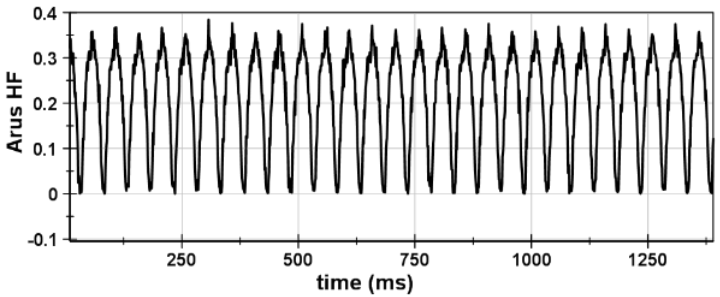

Gambar 11. Grafik kondisi normal 9 Lampu

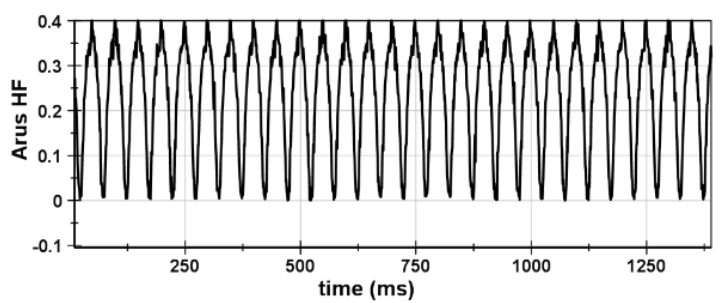

Gambar 12. Grafik kondisi normal 10 Lampu

Dari 10 gambar diatas dapat terlihat bahwa nilai arus maksimum pada kondisi normal pada keseluruhan eksperimen tidak ada yang melewati batas threshold arus 2 A. Pada gambar diatas juga menerangkan bahwa pada eksperimen kondisi normal tidak terdeteksi titik gangguan atau jumlah titik > threshold arus bernilai 0 pada semua percobaan. Dalam program pendeteksian, kedua threshold memiliki peran penting dalam membedakan ketiga kondisi. Sehingga jika kedua kondisi ini tidak terpenuhi maka indikator normal "ON" dan disimpulkan bahwa kondisi yang terdeteksi adalah kondisi normal. Selain itu juga akan ditampilkan 1 sample dari user interface program pendeteksian saat kondisi normal terdeteksi.

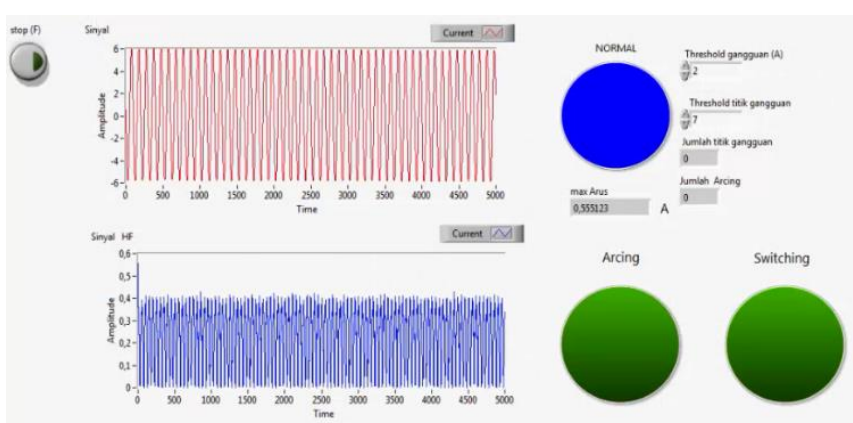

Gambar 13. Tampilan eksperimen kondisi normal 10 Lampu dalam program pendeteksian arcing tegangan rendah

Gambar diatas menunjukkan bahwa user interface program pendeteksian arcing tegangan rendah hanya mendeteksi keadaan normal, saat tidak terjadi penambahan beban atau gangguan, sehingga indikator normal "ON". Hal ini dikarenakan kedua threshold pada program pendeteksian belum ada yang terlampaui yaitu tidak melampaui threshold arus maupun threshold jumlah titik gangguan, sehingga pada user interface menunjukkan jumlah titik gangguan dan jumlah arcing yang bernilai “0”. Sedangkan untuk switching,

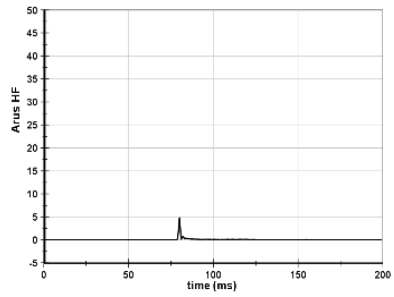

Gambar 14. Switching 1 Lampu

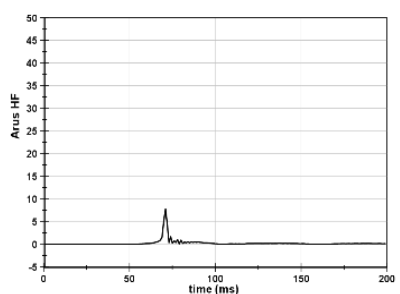

Gambar 15. Switching 2 Lampu

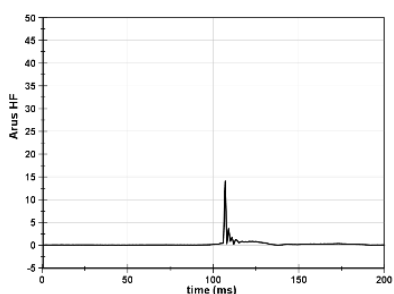

Gambar 16. Switching 3 Lampu

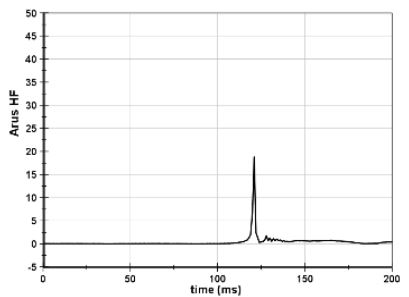

Gambar 17. Switching 4 Lampu

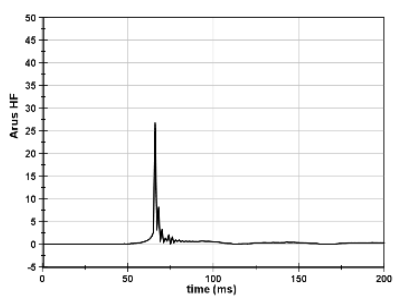

Gambar 18. Switching 5 Lampu

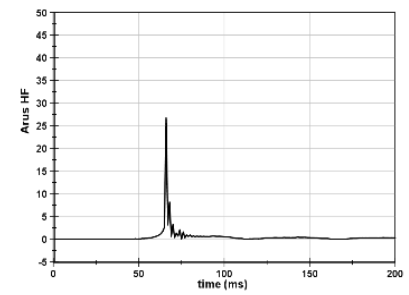

Gambar 19. Switching 6 Lampu

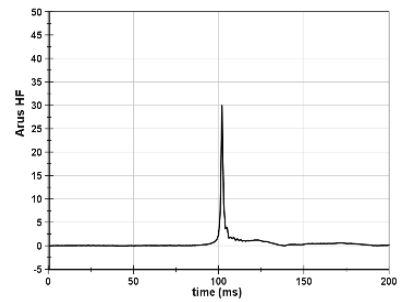

Gambar 20. Switching 7 Lampu

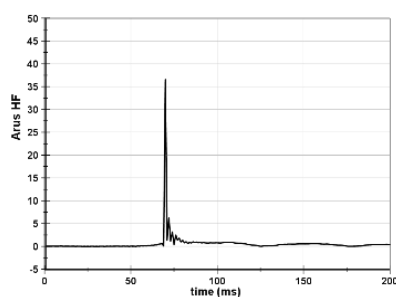

Gambar 21. Switching 8 Lampu

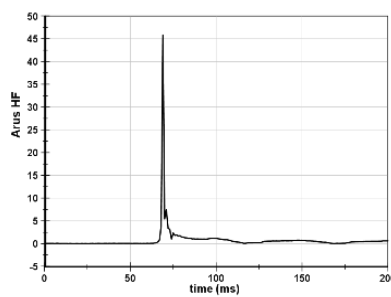

Gambar 22. Switching 9 Lampu

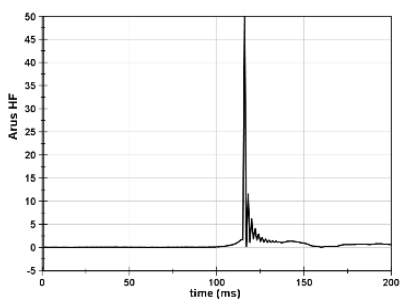

Gambar 23. Switching 10 Lampu
Dari grafik diatas, dapat dilihat bahwa saat terjadi switching nilai arus mengalami lonjakan yang sangat tinggi sehingga melewati threshold pertama namun jumlah titik tidak melebihi 7 sehingga hanya terdeteksi sebagai sebuah switching.

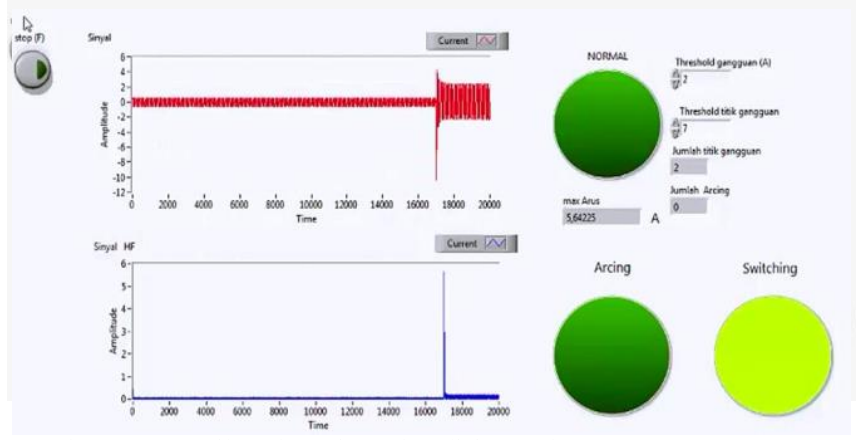

Gambar 24. Tampilan eksperimen kondisi switching 2

Sedangkan untuk capture gambar diatas menunjukkan bahwa terdapat lonjakan arus namun jumlah titik tidak 
melebihi 7 sehingga dari keseluruhan eksperimen akan terjadi perubahan dari normal menjadi switching (indikator switching “ON").

\section{Analisis Data Karakteristik Busur Api Listrik (Arcing) Tegangan Rendah pada Hubung Singkat Langsung}

Pada eksperimen busur api listrik (arcing) tegangan rendah dilakukan hubung singkat secara langsung antara 2 kabel yang umum digunakan pada instalasi tegangan rendah (pemukiman dan pasar). Parameter yang digunakan adalah 1 serabut, 3 serabut, 6 serabut, 12 serabut dan 24 serabut. Eksperimen ini menggunakan 10 lampu 100 watt dengan daya total yang 1000 watt, dengan tujuan pemodelan seperti instalasi listrik tegangan rendah yang umunya menggunakan daya 900 VA atau 1300 VA dengan tegangan 220 V. Grafik eksperimen 1,3,6,12 dan 24 serabut dapat dilihat pada gambar dibawah ini.

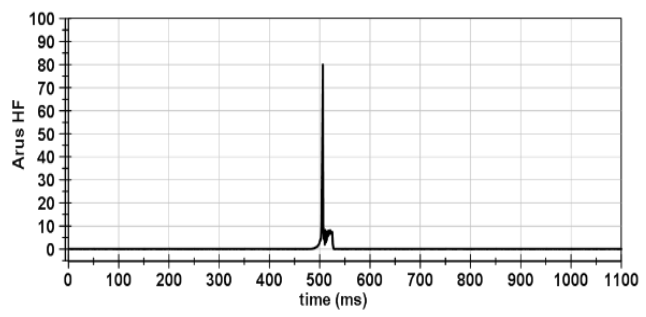

Gambar 25. Arcing 1 serabut

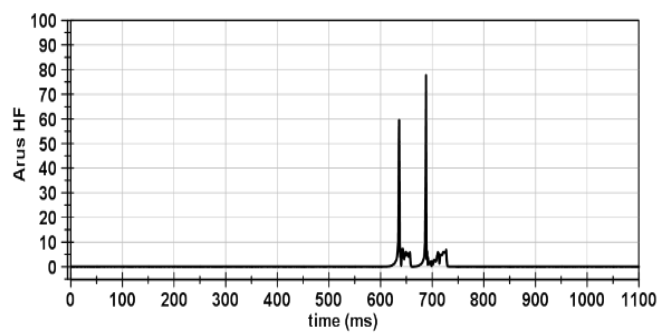

Gambar 26. Arcing 3 serabut

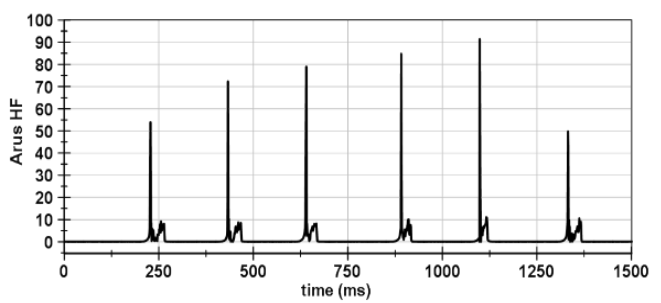

Gambar 27. Arcing 6 serabut

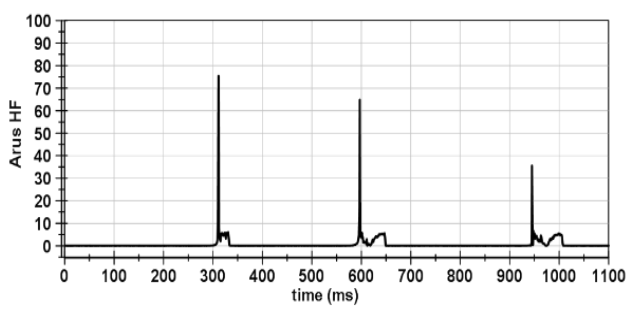

Gambar 28. Arcing 12 serabut

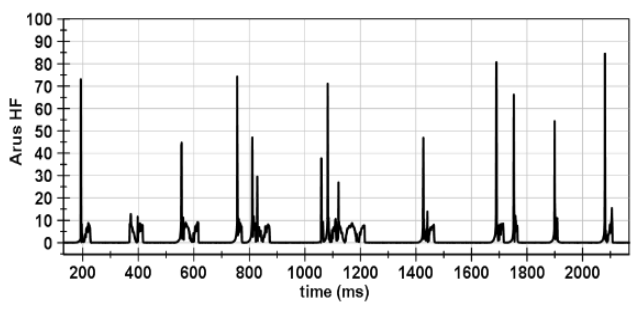

Gambar 29. Arcing 24 serabut

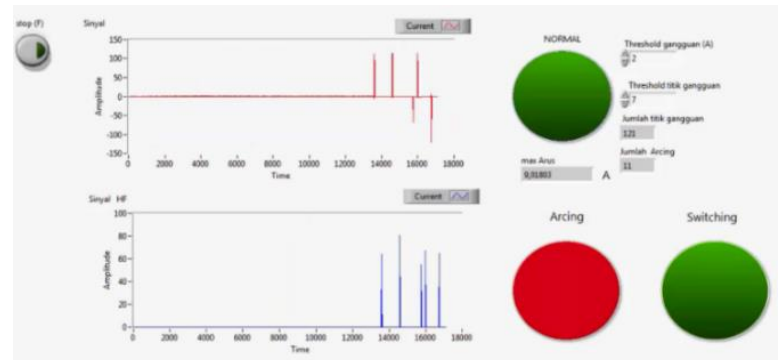

Gambar 30. Tampilan eksperimen kondisi arcing 12 serabut

\section{Analisis Probabilitas dan Persebaran Data}

Gambar grafik persebaran data dari keseluruhan eksperimen kondisi normal, penambahan beban dan arcing dapat dilihat pada beberapa gambar dibawah ini.

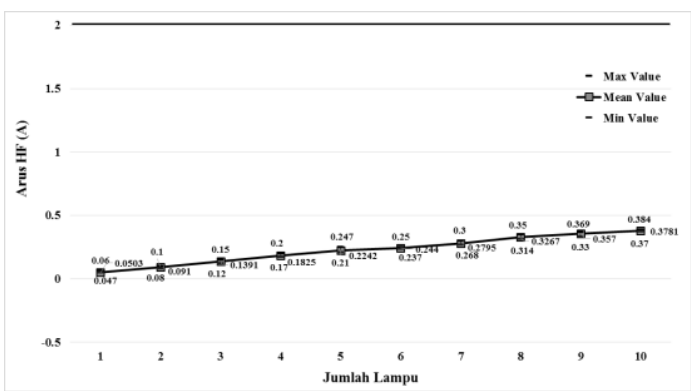

Gambar 31. Persebaran arus maksimum kondisi normal

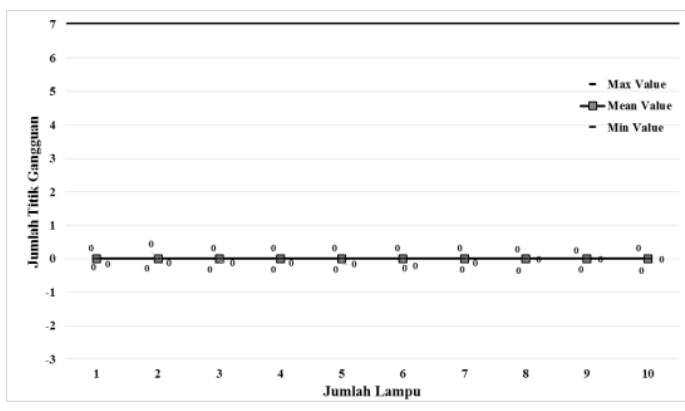

Gambar 32. Persebaran titik gangguan kondisi normal

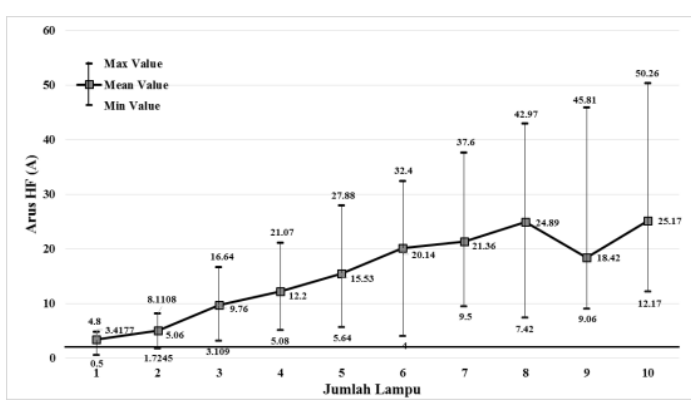

Gambar 33. Persebaran Arus Maksimum kondisi switching

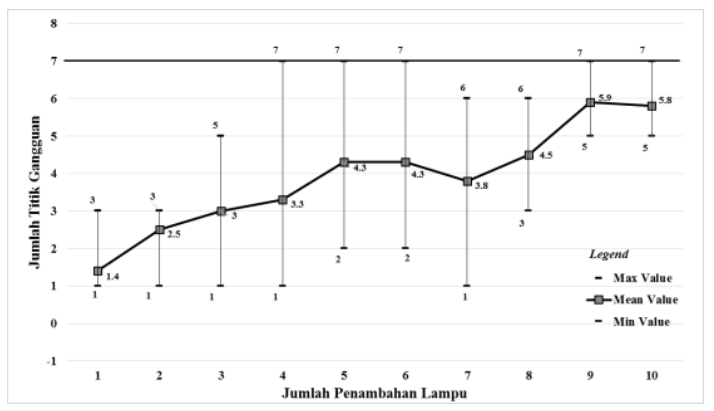

Gambar 34. Persebaran jumlah titik gangguan kondisi switching 


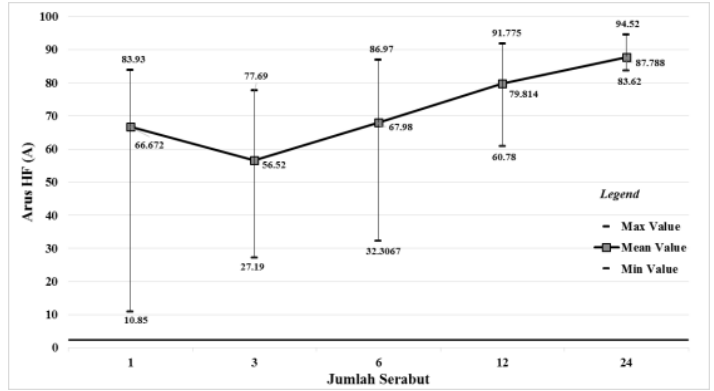

Gambar 35. Persebaran Arus Maksimum kondisi arcing

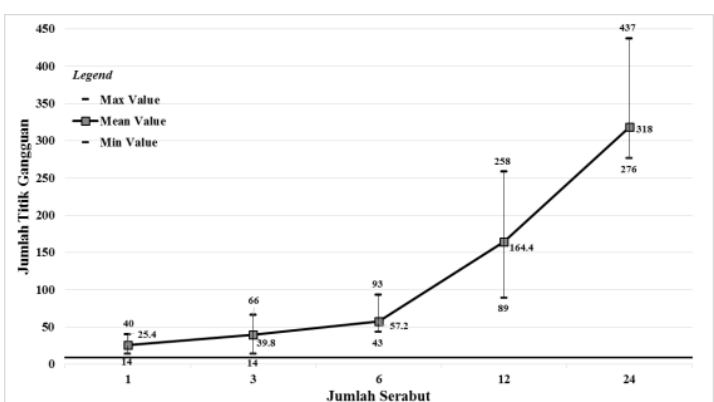

Gambar 36. Persebaran jumlah titik gangguan kondisi arcing.

Dapat dilihat dari keseluruhan grafik stockplot, persebaran data memiliki trend yang semakin meningkat pada setiap eksperimennya. Pada grafik eksperimen kondisi normal dapat dilihat bahwa grafik persebaran data nilai arus maksimum serta grafik persebaran titik gangguan tidak ada yang melebihi threshold nya masing masing. Untuk eksperimen penambahan beban (switching) dapat dilihat pada grafik persebaran data nilai arus maksimum sudah melewati thresholdnya, namun untuk grafik persebaran titik gangguan terlihat bahwa tidak ada yang melewati threshold titik gangguan yaitu 7 titik. Sedangkan untuk eksperimen arcing grafik persebaran arus maksimum dan titik gangguan menunjukkan trend yang meningkat secara signifikan dan dapat dilihat dari grafik ini bahwa kedua threshold telah terlampaui.

\section{KESIMPULAN}

Beberapa kesimpulan yang dapat diambil dari eksperimen deteksi dan implementasi peralatan deteksi arcing tegangan rendah berbasis LabView adalah sebagai berikut:

1. Discrete Wavelete Transform merupakan transformasi yang mentransformasi sinyal menjadi 2 dekomposisi yaitu low frequency $(L F)$ dan High Frequency $(H F)$, yang kemudian digunakan sinyal HF karena dekomposisi ini adalah detail.

2. Pada program pendeteksian dilakukan dengan 2 threshold yaitu threshold arus 2 A dan threshold jumlah titik gangguan sebanyak 7 titik.

3. Pada fenomena kondisi normal, sinyal tidak melampaui kedua batas, untuk kondisi penambahan beban hanya melewati threshold pertama serta kondisi arcing melampaui kedua threshold.

4. Variasi jumlah serabut pada eksperimen busur api listrik (arcing), berpengaruh terhadap fenomena pengulangan ignition, durasi terjadinya gangguan, jumlah arcing dan jumlah titik gangguan.

\section{SARAN}

Dalam Tugas Akhir ini telah mampu menunjukkan jumlah arcing, jumlah titik gangguan, sinyal asli, sinyal wavelet, serta tiga indikator program pendeteksian yaitu indikator normal, switching dan arcing.. Tugas akhir ini sudah menghasilkan indikator arcing yang dapat mendeteksi terjadinya gangguan hubung singkat secara real tme, namun penelitian ini belum dapat melakukan sinkronisasi dengan miniatur circuit breaker untuk melakukan tripping sehingga diperlukan peralatan mikrokontroller yang secara otomatis dapat melakukan tripping kepada MCB saat indikator arcing pada Labview "ON".

\section{DAFTAR PUSTAKA}

[1] K.Mishra, A.Routray, and A. K. Pradhan, "Detection of Arcing in Low Voltage Distribution Systems", IEEE Region 10 Colloquium and the Third International Conference on Industrial and Information Systems 2008, pp. 1-3.

[2] National Fire Protection Association, "NFPA 70E: Standard for Electrical Safety in the Workplace", NFPA 2004.

[3] Riza Fakhroun Nisa', Dimas Anton Asfani, dan I Made Yulistya Negara, "Analisis Karakteristik Busur Api Listrik Pada Tegangan Rendah Karena Pengaruh Impedansi Saluran Menggunakan Transformasi Haar Wavelet" Jurnal Teknik Pomits Vol. 1, No. 1, (2015)

[4] Tim penyusun, "Persyaratan Umum Instalasi Listrik 2000 (PUIL 2000)", Indonesia, 2000

[5] Asit K Mishra, Aurobinda Routray, Ashok K. Pradhan, "Detection of Arcing in Low Voltage Distribution Systems", IEEE Region 10 Colloquium and the Third International Conference on Industrial and Information Systems, Paper ID 502, Kharagpur, India, Desember, 2008.

[6] Tammy Gammon, John Matthews, "The Historical Evolution of Arcing-Fault Models for Low-Voltage Systems”, IEEE

[7] Dogan Gokhan,Ece . Francis M.,Wells Hakan G. Senel, "Analysis And Detection of Arcing Faults In Low-voltage Electrical Power Systems”, Department of Electrical Engineering Vanderbilt University Nashville, Tennessee USA, IEEE Conference Publications, 1994

[8] Berdasarkan data Badan Nasional Penanggulangan Bencana (BNPB) periode Agustus 2011-2015

[9] Yuan Wu, Zhengxiang Song and Xue Li, "A Method forArc Fault Detection Based on the Analysis of Signal's Characteristic Frequency Band with Wavelet Transform ", IEEE 2nd International Conference on Electric Power Equipment, Matsue, Japan, 2013

[10] G. Artale, A. Cataliotti, V. Cosentino, and G. Privitera, "Experimental Characterization Of Series Arc Faults In AC And DC Electrical Circuits, ”2014, pp. 1015-1020. 